\title{
Human Capital as a Basis for the Development of a Modern University
}

\author{
Aleksey Golikov ${ }^{1}$, Marina Kudaka $^{2}$, Vitaly Sergeev ${ }^{3,}{ }^{*}$, Irina Sergeeva ${ }^{4}$, Platon Tishin ${ }^{5}$, \\ and Elena Tumakova ${ }^{6}$ \\ ${ }^{1}$ North-Eastern Federal University, 677027 Yakutsk, Russian Federation \\ ${ }^{2}$ Cherepovets State University, 162600 Cherepovets, Russian Federation \\ ${ }^{3}$ Peter the Great St. Petersburg Polytechnic University, 195251 St. Petersburg, Russian Federation \\ ${ }^{4}$ Novosibirsk State University, 630090 Novosibirsk, Russian Federation \\ ${ }^{5}$ Tomsk State University, 634050 Tomsk, Russian Federation \\ ${ }^{6}$ Tyumen State University, 625003 Tyumen, Russian Federation
}

\begin{abstract}
Modern world trends have a significant impact on the university and human capital as an important part of the university. From our point of view, an active process is currently underway and namely it is transition from a university-function, to a university-subject of change. Only a small amount of the university's academic staff have the necessary competences for the implementation of full-life projects and the ability to work in a project team, this is primarily due to the lack of soft-skills. In this regard, to assess the capitalization of the human resource in the university community, in this article propose to introduce the concept of capitalization index (CI), which takes into account the diversity of activities of the university staff (scientific work, teaching, interaction with students, etc.) and determines its effectiveness. This system allows us to supplement it with various components, depending on the trends of development of the university, and also shift the focus from one area to another (priority factor) and strengthen the significance of a certain type of activity (quality factor).
\end{abstract}

\section{Introduction}

Dynamic development and rapid change in all spheres of modern life leads to a regular transformation of the educational policy of the university. Most researchers and experts agree that "today, at the beginning of the 21 st century, the world is on the verge of a new wave of innovation that can seriously change the existing "educational landscape" globally "[1]. University should transform from the institution, performing a specific social order, a certain function, but rather become the subject of changes that determine socio-economic policies region and / or country. Volkov A., Melnik D. in Vedomosti (Autonomy and Publicity of the University): "To make education good and interesting, it can not be exclusively the direct concern of centralized power, but should become the subject of concern for the universities themselves. In this sense, it is necessary to complete the transition from Soviet higher

\footnotetext{
*Corresponding author: vitaly_sergeev@mail.ru
} 
educational institution as a form of training of personnel for the branch ministry to a university as an autonomous organization risking in the market of reputation ".

Undoubtedly, the achievement of this goal is possible only if the attitude to human capital, which forms the basis of the university will change.

By human capital we mean university, teachers, students, employers and graduates, contributing to the increase of their own cost and university cost.

It is necessary to distinguish between the concepts "human capital" and " human resource," since not every employee and student of a university promotes capitalization. The human resource is people who exercise activities in the aging system, performing specified functions and not seeking development and self-determination in a new system of universitysubject of change (Table 1). However, under certain conditions, human resource could capitalize, assuming the role of human capital

Table 1. Comparative characteristic of human capital and resource.

\begin{tabular}{|c|c|c|}
\hline Attitude to activities & Human resource & Human capital \\
\hline Position at structure "I-future" & Thinks for today & Reflective Position \\
\hline Task & Save your resource & Capitalize yourself \\
\hline Action & $\begin{array}{c}\text { Act on the model - man- } \\
\text { function }\end{array}$ & $\begin{array}{c}\text { Mastering the field of action } \\
\text { - person - subject of change }\end{array}$ \\
\hline
\end{tabular}

A number of works are devoted to the study of the influence of human capital on the effectiveness of the organization. Meta-analysis examined the effects of three dimensions of HR systems - skills-enhancing, motivation-enhancing, and opportunity-enhancing - on proximal organizational outcomes (human capital and motivation) and distal organizational outcomes (voluntary turnover, operational outcomes, and financial outcomes) was presented in work [2]. Article [3] offers a new approach to the conceptualization of the human capital resource by developing a multilevel model. Also a number of works are aimed at studying the development of universities [4-7] where the engine of development is human capital [8$10]$.

\section{Human capital in academic area}

One of the goals of the development of education is the creation of competitive universities [11]. Most universities consider themselves capable of participating in this process, but a practical understanding of realisation of this task is often absent. An important role in this process is played by the human capital of the university.

The academic staff of the university determines the indicators of the publication activity, citation, academic reputation, reputation in business, internationalization.

In accordance with international ISO standards, universities should provide their work by personnel of the appropriate qualifications, identifying the necessary level of competence of employees, organizing their selection and training with due effectiveness, motivating staff to quality work [12].

At the same time, there is no common understanding of the evaluation and effectiveness of these indicators, as well as benchmarks, how these functions can be developed in human capital of the university.

In this regard, to assess the capitalization of the human resource in the university community, we propose to introduce the concept of capitalization index (CI), which takes into account the diversity of activities of the university staff (scientific work, teaching, interaction with students, etc.) and determines its effectiveness: 


$$
\begin{gathered}
\mathrm{CI}=\mathrm{CI}(\text { Science })+\mathrm{CI}(\text { Education })+\mathrm{CI}(\text { Innovation })+\mathrm{CI}(\text { Politics })+\mathrm{CI}(\text { Intra- } \\
\text { university environment })+\mathrm{CI}(\text { Media })
\end{gathered}
$$

At the same time, the capitalization index (CI) takes into account the priority indicators and the quality of their implementation:

$$
\mathrm{CI}(\mathrm{X})=\text { Points }(\mathrm{X}) \bullet \text { Priority factor }(\mathrm{PF}) \bullet \text { Quality factor }(\mathrm{QF})
$$

This system allows us to supplement it with various components, depending on the trends of development of the university, and also shift the focus from one area to another (priority factor) and strengthen the significance of a certain type of activity (quality factor).

Modern world trends have a significant impact on the university and human capital as an important part of the university. A correct assessment of human capital has allowed the formation of effectively working students research groups receiving new scientific results (for example [13-14]) and create conditions for the application of modern educational technologies (for example [15-17]).

Positive effects of trends can be identified as follows:

1. Globalization in science, leading to the cooperation of scientists from different countries, and also the strengthening of the influence of the Asian region. Globalization leads to processes of division of labor on a global scale.

2. Networking with the concentration of technology and recognition of belonging to various network interrelationships. Well developed partner scientific research system will allow organizing a large number of interdisciplinary research, that are the most promising for the development of science in universities nowadays.

3. Demographic shifts that promote the active life position of the group $60+$, both among the faculty and students of the university. The prospective direction of the influence of this trend is development of the system of continuous education in various fields of human activity. The challenge of the present time is the trend "I have to study all life ", realizing person's need for self-development.

4. The introduction of an artificial intelligence system in areas with high risks, for example, when recruiting staff.

5. Digitalization of the modern world, which leads to a reduction in labor-intensive work, the reduction of the terms of training, the integration of various fields of knowledge and increase in free time.

6. Ecologization, involving the emergence of a huge number of new opportunities for application of research and development of technologies in which the university can play a leading role. Ecologization causes the search for new values, such as a healthy lifestyle, readiness for self-development.

These same trends have a negative impact. So, globalization, allowing to choose not only an educational institution for students, but also a workplace for teachers, leads to redistribution of teaching staff and concentration of people with active life position in certain universities.

Networking contributes to a more extensive stratification of society and strengthening the influence of mass media, leading to imitation of a person's spiritual life.

Artificial intelligence allows you to create more stable technological platform than the structures implemented by man.

Demographic shifts lead to the emergence of a new generation of children with different requirements and requests to the education system, which does not always find opportunities for their satisfaction.

Ecologization leads to an increase in the cost of technological processes, complicating the research and implementation of new developments.

If we consider the most significant "gaps" between positive action trends and the real situation of the state of human capital, we can distinguish a number of features. 
The trend of digitalization - the active conduct of classroom activities is still performed by the faculty, lecture courses are up to $30 \%$ of classroom work, only single teachers in universities have their own on-line courses.

In the networking - collaborations assume the dependence of Russian colleagues on foreign partners, who usually develop research design and are the main executors of most projects.

Globalization is reflected in the fact that, at least one in three students ( according to recent polls) is not going to look for Russian employers, but rather choose to work abroad, or at least in Western firms.

Demographic shifts lead to a shortage of teachers of young and middle age, in 2017, 39 $\%$ of university professors were over 55 .

The trend of ecologization is not sufficiently taken into account by most universities. So, for example, biomedical research in the world remains at the peak of relevance, but only 10 Russian universities with medical specialties (out of 89) have their own university clinics, in which such studies are possible.

The current situation of the development of universities is characterized by a number of external problems, such as: high speed of changes in educational technologies and processes, increasing competition in science, digitalization of communication. These problems are exacerbated by the specifics of the regulatory framework, which fixes the current situation, without assuming dynamic changes in the education process, and also, changes in occupations and activities that are difficult to predict [18].

In most Russian universities there are internal problems, fixing the framework of human capital. Among them there are problems of economic and social nature. Conservatism of the university in adopting management decisions leads to a sufficiently long time for the introduction of new structures. For example, creation of small investment enterprises within the structure of the university takes up to 6 months, admission process of an off-system employee - about 5 months, and the dismissal of an ineffective employee at the initiative of the administration is practically impossible. It is important to understand that the need to avoid a stationary system, where personnel is formed, is mandatory, especially in the context of new systems, where benchmarks of activity are constantly changing.

Only a small amount of the university's academic staff have the necessary competences for the implementation of full-life projects and the ability to work in a project team, this is primarily due to the lack of soft-skills. Lack of this competence does not allow employees to become involved in the university activities quickly enough, and the majority causes internal resistance to these changes. All this lead to the formalization of the curricula and the competencies. Absence of identification with changes in the educational process is typical for most faculty members of universities. First of all, this is due to the desynchronization of personal goals with the goals of the university.

The hierarchy of values in the structure of the university is determined by the pedagogical experience and scientific degree. The degree of candidate and doctor of science in universities is qualification indicator of stereotyped personnel policy (requirements for availability of $80 \%$ of teachers with a degree in the specialty profile) and the main characteristic of the long stepped path of building career tracks. Wherein the requirements do not include such indicators as the level of relevance of scientific research and participation in the international scientific division of labor.

There are 5 mechanisms for the formation of human capital: mobility, scientific agenda, interaction with the environment, education, innovation. Existing and prospective situations with regard to these mechanisms have universal character (Table 2). 
Table 2. Mechanisms of formation of human capital.

\begin{tabular}{|c|c|c|}
\hline Mechanism & Situation & Perspective \\
\hline Mobility & Inbreeding & $\begin{array}{c}\text { Ascendant and Outgoing } \\
\text { mobility, free exchange }\end{array}$ \\
\hline Scientific Agenda & $\begin{array}{c}\text { The traditions of scientific } \\
\text { schools }\end{array}$ & $\begin{array}{c}\text { Defined by international division } \\
\text { of labor }\end{array}$ \\
\hline $\begin{array}{c}\text { Interaction with } \\
\text { environment }\end{array}$ & $\begin{array}{c}\text { The region has an impact on } \\
\text { the University }\end{array}$ & $\begin{array}{c}\text { University accumulates world } \\
\text { knowledge and can provide it to } \\
\text { the region }\end{array}$ \\
\hline Education & Sealed educational & $\begin{array}{c}\text { Communication and } \\
\text { transdisciplinarity }\end{array}$ \\
\hline Innovations & $\begin{array}{c}\text { Services for business, market } \\
\text { determines the innovative } \\
\text { agenda }\end{array}$ & $\begin{array}{c}\text { University forms the market of } \\
\text { innovations }\end{array}$ \\
\hline
\end{tabular}

\section{Conclusion}

Thus, from our point of view, an active process is currently underway and namely it is transition from a university-function, to a university-subject of change. For universityfunction it is characteristic to fulfill the order (education, professional qualification, educational conveyor), for university- subject to change it is important to create the environment, new trends and directions, high level of skills, motivation of all participants of educational process for development, inter-institutional interaction and individual development trajectories [19]. In this process, human capital plays an important role, the increase in its amount, in relation to human resource of the university is a priority[3,20].

\section{References}

1. D. Konanchuk A. Volkov, The era of "greenfield" in education. (LLS Skolkovo, Moscow, 2013)

2. K. Jiang, D.P. Lepak, J. Hu, J.C. Baer, Academy of Management Journal 55, 12641294 (2012), doi:10.5465/amj.2011.0088

3. R. Ployhart, T. Moliterno, Academy of Management Review 36, 127-150 (2011), doi:10.5465/amr.2009.0318

4. M. McAdam, K. Miller, R. McAdam, R and D Management 47, 458-472 (2017), doi: $10.1111 / \mathrm{radm} .12265$

5. Å. Gornitzka, P. Maassen, H. de Boer, Higher Education Quarterly 71, 274-289 (2017), doi:10.1111/hequ.12127

6. O.V. Konina, E.D. Nanetadze, Managing a modern university: The role of business processes in the structure of establishments of higher professional education; Vol. 726; ISBN 9783319908342

7. G. Fernandes, A.R. Martins, E.B. Pinto, M. Araújo, R.J. Machado, Risk response strategies for collaborative university-industry $R \& D$ funded programs; Vol. 505; ISBN 9783319913339

8. J.M. Unger, A. Rauch, M. Frese, N. Rosenbusch, Journal of Business Venturing 26, 341-358 (2011), doi:10.1016/j.jbusvent.2009.09.004

9. L. Gratton, V. Hope-Hailey, P. Stiles, C. Truss, Human Resource Management 38, $17-$ 31 (1999) 
10. S. Mithas, N. Ramasubbu, V. Sambamurthy, MIS Quarterly: Management Information Systems 35, 237-256 (2011)

11. JG Vissema. University of the third generation: university management in transition period. (Olimp-Business, Moscow, 2016)

12. ISO / IWA Standard 2: 2007 "Quality Management Systems - Guidelines guidance on the application of ISO 9001: 2000 in education " (International Organization for Standardization, 2007)

13. A.V. Vakhrushkina, A.V. Mishakova, K.D. Borshcheva, Magazine of Civil Engineering 71, 30-38 (2017), doi:10.18720/MCE.71.4

14. Y.G. Barabanshchikov, S.V. Belyaeva, I.E. Arkhipov, M.V. Antonova, A.A. Shkolnikova, K.S. Lebedeva, Magazine of Civil Engineering 74, 140-146 (2017), doi:10.18720/MCE.74.11

15. A.E. Bolotin, D.B. Selyukin, Teoriya i Praktika Fizicheskoy Kultury, 32-34 (2015)

16. A.A. Gorelov, R.M. Gadel'shin, S.N. Nikitin, Teoriya i Praktika Fizicheskoy Kultury, 62-64 (2014)

17. O.M. Khudolii, O.V. Ivashchenko, S.S. Iermakov, O.G. Rumba, Science of Gymnastics Journal 8, 215-228 (2016)

18. P.Luksha., K.Luksha, D.Varlamova, D.Sudakov, D.Peskov, D.Korichin, Atlas of new professions (LLS Skolkovo, Moscow, 2015)

19. S. Amoroso, A. Coad, N. Grassano, Economics of Innovation and New Technology 27, 404-419 (2018), doi:10.1080/10438599.2017.1374037

20. W.K. Smith, Academy of Management Journal 57, 1592-1623 (2014), doi:10.5465/amj.2011.0932 